\title{
CORRECTION
}

\section{Correction to: An Assessment of Competitiveness of Technology-Based Startups in India}

\author{
Krishna Satyanarayana $\left(\mathbb{D} \cdot\right.$ Deepak Chandrashekar $^{1}\left[\right.$ ] $\cdot$ Bala Subrahmanya Mungila Hillemane ${ }^{2}(\mathbb{0}$
}

Published online: 3 August 2021

(c) Global Institute of Flexible Systems Management 2021

\section{Correction to: International Journal of Global Business and Competitiveness (2021) 16:28-38 \\ https://doi.org/10.1007/s42943-021-00023-x}

This article was published online first on 17. May 2021 with a wrong file as Supplementary Information. This has now been corrected.

The original article was not affected by this correction.

The original article can be found online at https://doi.org/10.1007/ s42943-021-00023-x.

Deepak Chandrashekar

deepakc@iimb.ac.in

Krishna Satyanarayana

krishna.hs@iimb.ac.in

Bala Subrahmanya Mungila Hillemane

bala@iisc.ac.in

1 Indian Institute of Management Bangalore, Bangalore, India

2 Department of Management Studies, Indian Institute

of Science, Bengaluru, India 